\title{
CAROTENOIDS AND VITAMIN A IN THE BLOOD OF DAIRY CALVES IN PUERTO RICO
}

\author{
F. J. MARCHĀN, ${ }^{1}$ L. RIVERA BRENES ${ }^{2}$ AND L. F. COLÓN ${ }^{3}$
}

During the past years the Agricultural Experiment Station of the University of Puerto Rico has undertaken a series of fundamental studies in the nutrition of the dairy cow in this Island with the purpose of determining which nutritive factors are operating in such a way as to limit milk production. The low production of the dairy cow in Puerto Rico might possibly be the result of the poor growth and development of our dairy calves, which result in undersized cows with a lower productive capacity. Observations made at this Station ${ }^{4}$ show that the growth of the Holstein calves does not compare favorably with the Missouri standards (9) for that breed. Calf losses before three months of age have been heavy in recent years; 28 per cent in 1946, 19 per cent in 1947 and 29 per cent in 1948. These deaths have been due to scours, pneumonia and unknown causes, perhaps nutritional deficiencies. Although no symptoms of vitamin-A deficiency had been observed this study was started in order to ascertain whether or not our calves were being supplied with adequate amounts of this nutrient whose importance in calf nutrition has been definitely established.

Modern feeding and managerial practices among dairy calves have been one of the major obstacles to herd improvement. Moore and Berry (7) found that when calves were reared according to present-day methods of limited whole-milk feeding, the vitamin A content of the blood plasma from birth to four months of age was in the deficient range, as judged by blood values of vitamin-A deficient calves 4 to 14 months of age. Wise et al. (13) found that the vitamin-A content in the blood serum of calves at five weeks of age was 50 per cent lower than it was at the colostrum feeding period. Moore et al. (8) reported that the vitamin-A content of the blood plasma of dairy calves reared on a limited whole milk program was one third lower than that of beef calves of the same age that were permitted to suckle and thus obtained considerable more milk. Jacobson et al. (3) reported that calves permitted to run with their dams on pasture required four months on a vitamin-A deficient ration to deplete their reserves, while those reared according to present methods of limited whole milk feeding with hay of above average quality, required a depletion time of 2 to 4 weeks. Wise et al. (13) at the Kansas Agricultural Experiment Station have shown that

${ }^{1}$ Assistant Chemist, Animal Husbandry Department.

2 Acting Head, Animal Husbandry Department.

${ }^{3}$ Research Assistant Chemist, Animal Husbandry Department.

${ }^{4}$ Unpublished data, Agricultural Experiment Station, Río Piedras, Puerto Rico. 
during the interim between colostrum ingestion and effective hay consumption there was a marked decrease of vitamin-A and carotene in the blood of calves and they recommended vitamin-A supplementation during this period. With this information at hand, it was decided to study the vitamin-A and carotene content of the blood of a group of dairy calves, compare them with those in the States and determine whether or not it was necessary to supplement the calf ration.

\section{METHODS}

Twelve calves born at this Station from October 9, 1948 to March 21, 1949 were used in this study. The following breeds and crosses were represented: purebred Holstein, purebred Natives, grade Holsteins, Brown Swiss $\mathrm{x}$ Native and Holstein $\mathrm{x}$ Native. Immediately after birth and before ingestion of colostrum, the calves were bled and the carotene and vitamin-A determined by the method of Kimble (5). Thereafter determinations were made 24 and 72 hours after birth and when the calves were one, two, three and four months old. After the first sample of blood was drawn the calves were allowed to suckle from their dams, with whom they were kept for the first three days. Then they were removed to individual pens and fed whole milk from the Station herd at the rate of 10 per cent of their body weight. Five or six days after birth the calves were offered some grain and green Merker grass (Pennisetum purpureum var. Merkeri) with an average carotene content of $11.0 \mathrm{mg}$./ $\mathrm{lb}$. on a fresh basis. ${ }^{5}$ When the calves were one month old they were given reconstituted skimmilk until six-months of age with the exception of calves number four and number eleven which were given powdered skimmilk at the same rate and of calf number five which was changed to a yeast ration when two months old.

\section{RESULTS AND DISCUSSION}

Table 1 presents the carotene and vitamin-A values obtained for the calves under study.

A summary of the statistical analysis of the data is presented in tables 2 and 3.

Statistical analysis of the data showed that there is a significant difference in carotene and vitamin-A content between ages, the deviations from linearity being not significant (figure 1). Results obtained by other workers, Hansen, Phillips and Rupel (1), Hansen, Phillips and Smith (2) and Moore and Berry (6) show that the concentration of carotenoids and vitamin-A in the blood serum of dairy calves were low at birth, increased markedly after colostrum ingestion and then declined until the fifth week, when they started to increase again. These results were confirmed by Wise et

${ }^{5}$ Unpublished data, Agricultural Experiment Station, Río Piedras, Puerto Rico. 


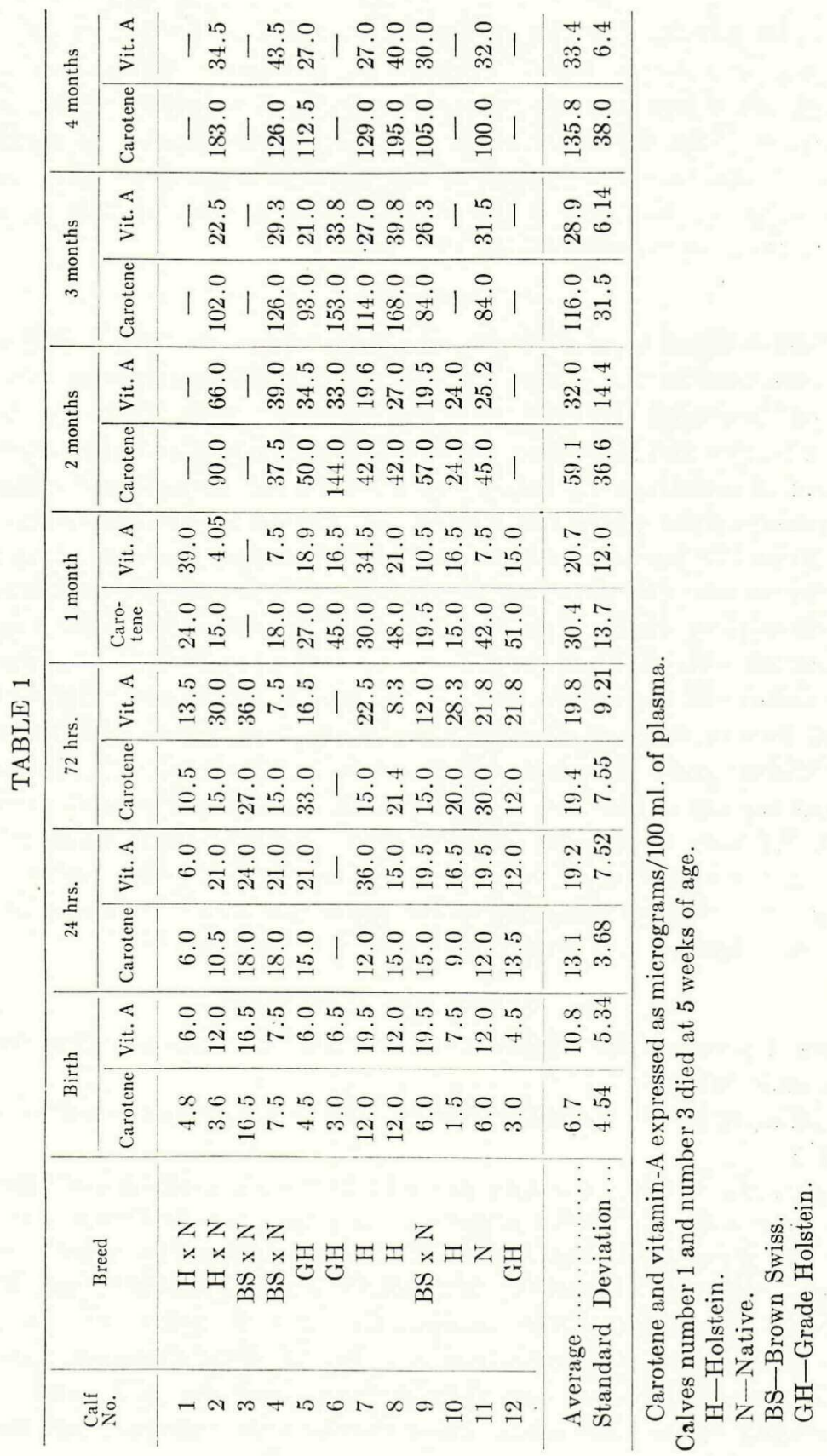


al. (13) who recommended vitamin-A supplementation during this period. The information obtained from our study shows that although the increase in carotene and vitamin-A after colostrum ingestion is not so marked as compared to the States, there is no need of supplementation since these constituents continue increasing steadily up to four months of age, the period of decline reported in the literature being totally absent. This continuous increase in carotene and vitamin-A can probably be explained on the basis of a larger reserve stored up in the liver of the calf during

TABLE 2

\begin{tabular}{|c|c|c|c|c|}
\hline Source of variation & DF & SS & Mean Square & $\mathrm{F}$ value \\
\hline 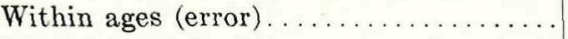 & 62 & $29,142.12$ & 470.03 & \\
\hline Linear regression $\ldots \ldots \ldots \ldots \ldots \ldots \ldots$ & 1 & $132,973.56$ & & \\
\hline Deviation from linearity......... & 5 & $(4,509.85)$ & 901.97 & 1.91 \\
\hline Age $\ldots \ldots \ldots \ldots \ldots \ldots \ldots \ldots$ & 6 & $137,483.41$ & $22,913.90$ & 48.74 \\
\hline Total ...... & 68 & $166,625.53$ & & \\
\hline
\end{tabular}

TABLE 3

Summary of statistical analysis for vitamin-A

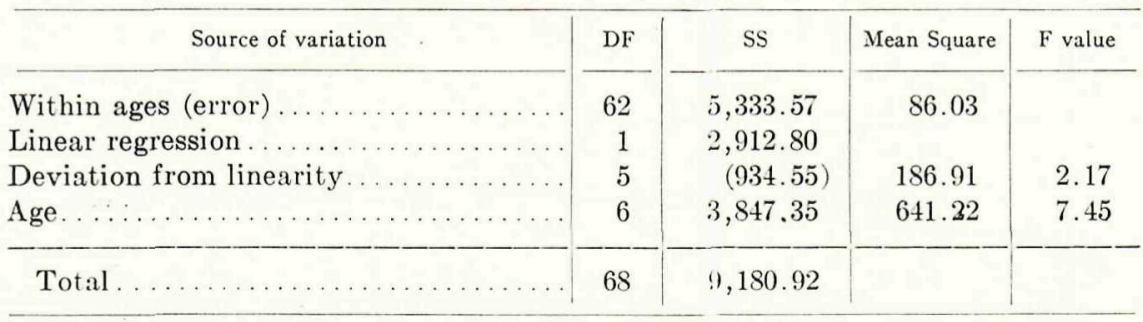

prenatal development due to the fact that their dams have been on green pasture all the year round.

In its report of 1945 the National Research Council (9) recommended for dairy cows a daily allowance of $90 \mathrm{mg}$. of carotene during the last 6 to 12 weeks before parturition. The fact that carotene requirements are lower at higher temperatures (4) suggests that in the tropics the requirements might be less. As our cows eat daily about 7 pounds of Merker grass per 100 pounds of live weight with an average content of $11.0 \mathrm{mg}$. of carotene per pound, their intake is considerably above their requirements. This permits the prenatal calf to store an ample supply in its liver, which can be used in the critical period comprised after colostrum ingestion and before effective grass consumption. 
The carotene and vitamin-A values obtained at birth $1,2,3$ and 4 months were compared with those given by Warner (12), Spielman (11), Wise (13) and Keener (4) for normal well-developed calves and in all cases our values compared favorably with those given by these authors. The results obtained are a strong indication that up to 4 months of age, vitamin$\mathrm{A}$ is not a factor affecting the growth and development of our calves. It is logical to believe that high mortality and the slow rate of growth are probably due to some other causes. .

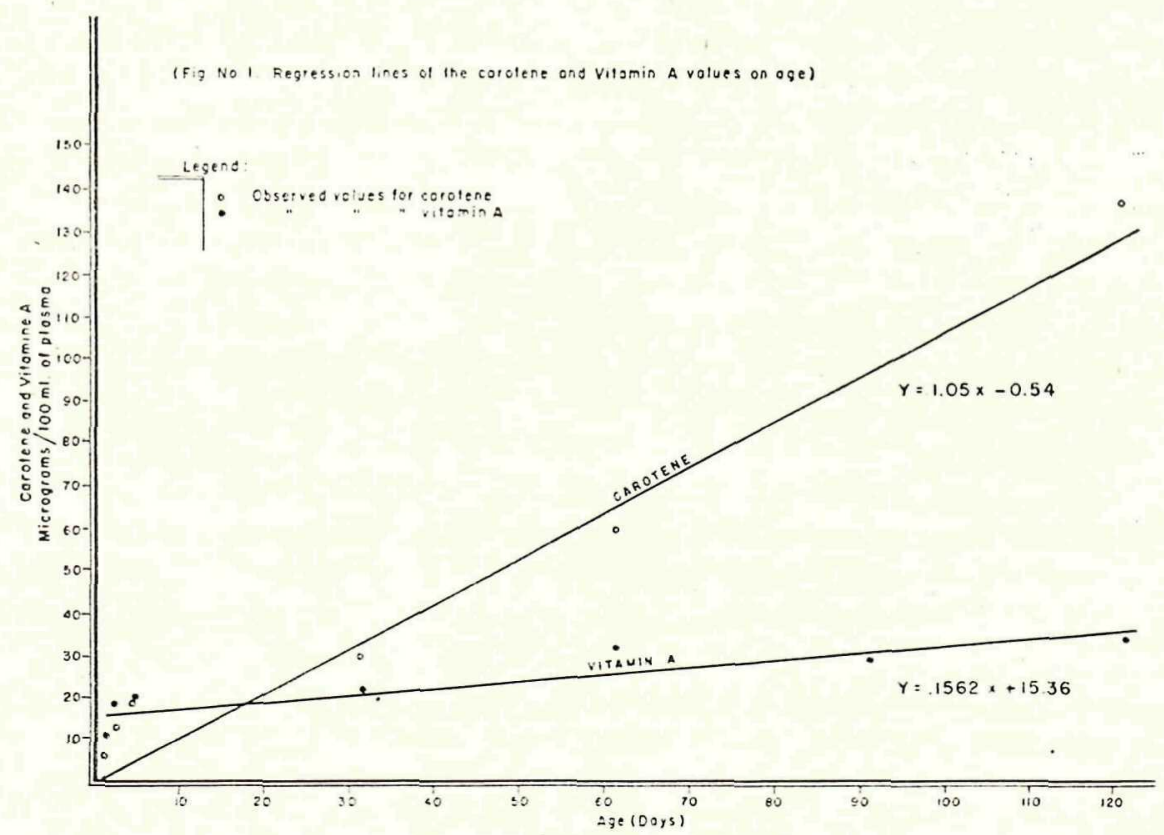

FIG. 1. Regression lines of the carotene and Vitamin A values on age.

\section{SUMMARY AND CONCLUSIONS}

The carotene and vitamin-A content of the blood of a group of dairy calves was determined at birth, before ingestion of colostrum, 24 and 72 hours after birth, and thereafter at monthly intervals until 4 months of age.

There was a significant difference in carotene and vitamin-A between ages, the relationship being best described by a straight line. Carotene and vitamin A values compared favorably with those given in the United States for normal calves.

Supplementation with vitamin-A during the period comprised between 
the third day after birth and effective grass consumption (5 weeks of age) is considered unnecessary.

\section{ACKNOWLEDGMENT}

The authors wish to express their appreciation to Mr. Antonio González Chapel for his help in the statistical analysis.

\section{LITERATURE CITED}

1. Hansen, R. G., Phillips, P. H. and Rupel, I. W. The effect of vitamin supplements upon survival of new-born calves. J. Dairy Sci. 29: 760, 1946.

2. Hansen, R. G., Phillips, P. H., And Smith, V. R. Colostrum milk and its vitamin-A content. J. Dairy Sci. 29: 809-814, 1946.

3. Jacobson, W. E., Converse, H. T., And Moore, L. A. Effects of vitamin-A and carotene intake on depletion time of young dairy calves. J. Dairy Sci., 32: 418-428, 1949.

4. Keener, H. A., Beckdel, S. I., Guerrant, N. G., and Thorp, W. T. S. Carotene in calf nutrition. J. Dairy Sci. 25: 571-583, 1942.

5. Kimble, M. S. The photoelectric determination of carotene and vitamin-A in human plasma. J. Lat. Clin. Med., 24: 1055-1065, 1939.

6. Moore, L. A., ANd Berry, M. H. Effect of colostrum on the vitamin-A and carotene content of new born calves. J. Dairy Sci., 27: 867-873, 1944.

7. Moore, L. A., ANd BerRy, M. H. Vitamin-A and carotene content of the blood plasma of dairy calves from birth up to four months of age. J. Dairy Sci., 28: 281-286, 1945.

8. Moore, L. A., Berry, M. H., And Sykes, J. F. Carotene requirements for the maintenance of a normal spinal fluid pressure in dairy calves. J. Nutrition 26: $649-658,1943$.

9. National Research Council No. 3. Recommended nutrient allowances for dairy cattle. Aug. 1945.

10. Ragsdale, A. C. Growth standards for dairy cattle. Mo. Agr. Expt. Sta. Bul. $336,1934$.

11. Spielman, A. A., Eaton, H. D., Loosli, J. K., And Turk, K. L. The effect of prepartum vitamin-A supplementation on the health and performance of the young calf. J. Dairy Sci., 32: 367-374, 1949.

12. Warner, R. G., And Sutton, T. S. The nutrition of the newborn dairy calf. J. Dairy Sci., 31: 976-985, 1948.

13. Wise, G. H., Caldwell, M. J., Parrick, D. B., Athinson, F. W., and Hughes, J. S. Relation of typical postnatal changes in the diet of the dairy calf to the concentration of carotenoids and vitamin-A in the blood serum. J. Animal Sci., 7: 70-77, 1948. 